\title{
Feuer und Flamme
}

_ Kennen Sie das? Man hat eine Idee, ist Feuer und Flamme, schmiedet Pläne und macht sich an die Umsetzung. Je intensiver man darüber nachdenkt und sich mit Familie und Freunden darüber austauscht, umso eher merkt man, wo die Idee noch hakt. Oder aber, es stellt sich heraus, dass sie der absolute Superknaller ist.

_ Vor etwa einem Jahr waren auch wir hier in der Redaktion Feuer und Flamme - und zwar für unsere Idee, den praxisprofi „ins Heft zu holen“. Wir diskutierten, verwarfen erste Entwürfe, überlegten uns neue und hatten am Ende ein - wie wir finden - tolles Konzept ausgearbeitet. Seit Januar setzen wir es um. Die Frage ist nun: Haben wir Ihren Geschmack getroffen, oder hakt das Konzept noch an der einen oder anderen Stelle? Machen Sie mit bei

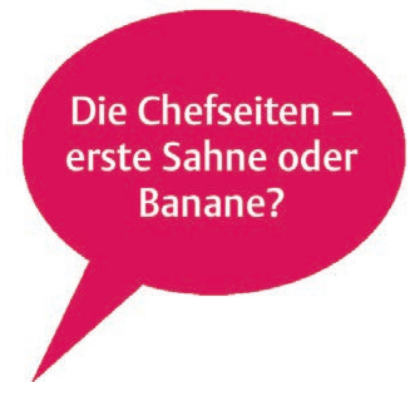
unserer Blitzumfrage. Wir freuen uns über Ihre Rückmeldungen, mit denen wir den Chefseiten vielleicht sogar ein Sahnehäubchen aufsetzen können.

Herzliche Grüße

Ihre
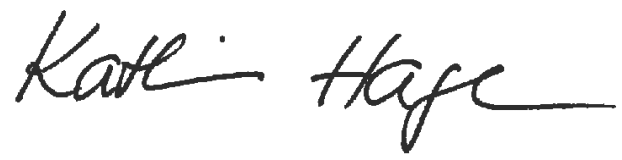

PS: Auch privat bin ich Feuer und Flamme, musste aber in diesem Fall nicht lange nachdenken, bevor ich „Ja“ sagte. Darum auch mein neuer Nachname :-)
Trifft praxisprofi Ihren Geschmack? Machen Sie bis zum 12.10.2014 mit bei unserer Blitzumfrage unter bit.ly/Leserumfrage_praxisprofi.

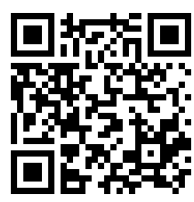

